\title{
The Great Experiment: The Admission of Women Students to St Mary's Hospital Medical School, 1916-1925
}

\author{
JAMES STUART GARNER*
}

The subject of women's entry to the medical profession has received considerable historical attention over the years. ${ }^{1}$ Parts of the story have acquired an almost mythological quality in recounting the extraordinary perseverance of a few dedicated women, which led to their eventual triumph over the professional self-interest of the male medical cabal in the latter years of the nineteenth century. ${ }^{2}$ Sometimes these accounts fall short of historical impartiality. For example, one book begins with the declaration "this book has five heroines". ${ }^{3}$ It is admirable that the author nails her colours to the mast with such abandon, but her bias undermines the work in the eyes of more temperate historians. Another describes the tribulations of Sophia Jex-Blake as "a true battle for liberty against tyranny, for the powers of light against the powers of darkness". ${ }^{4}$ Part of the reason for this slant is that some of the first accounts of the period were written by the female protagonists themselves, ${ }^{5}$ while subsequent work has sometimes been coloured by

*James Stuart Garner, BSc, MBBS, House Officer, St Mary's Hospital, Norfolk Place, London W2 1PG.

This paper concludes a series of researches that has occupied me for some time now, and which I began while reading for an intercalated BSc at the Wellcome Institute for the History of Medicine, in London. I am grateful to the Royal Society of Medicine for awarding the Norah Schuster Prize 1995 to an earlier incarnation of this work. Their support, moral and financial, has enabled me to take it a little further, Considerable thanks are also due to Dr Michael Neve, at the Wellcome Institute, for exhorting me to produce this paper and for providing crucial criticism of earlier drafts. Professor Bill Bynum at the Wellcome Institute has also been extremely generous with his advice and encouragement. In addition, I am indebted to Kevin Brown, archivist at St Mary's Hospital and Medical School, who has tirelessly furnished his wisdom and support over the course of this project, and without whom this would not have been possible. The merits of this paper reflect these individuals; its defects are purely my own.

\footnotetext{
1 Perhaps the first significant account is E
} Moberly Bell, Storming the citadel: the rise of the woman doctor, London, Constable, 1953.

2 A modern account to be framed in these terms is Catriona Blake, The charge of the parasols: women's entry to the medical profession, London, Women's Press, 1990.

${ }^{3}$ Edythe Lutzker, Women gain a place in medicine, London, McGraw-Hill, 1969, p. 1.

${ }^{4}$ Susan Kingsley Kent, Sex and suffrage in Britain, 1860-1914, Princeton University Press, 1987, p. 60.

5 For example, Elizabeth Blackwell, Pioneer work in opening the medical profession to women, London, Longmans, Green, 1895; Sophia Jex-Blake, Medical women: a thesis and history, Edinburgh, Oliphant, Anderson \& Ferrier, 1886; Louisa Martindale, The woman doctor and her future, London, Mills \& Boon, 1922. 


\section{Women Students at St Mary's Hospital Medical School}

contemporary feminism. ${ }^{6}$ At any rate, the myth of objective history is at its weakest in this field. ${ }^{7}$

Moreover, it is a misapprehension to believe that women's entry to medicine was an essentially nineteenth-century phenomenon. ${ }^{8}$ It is easy to forget that, notwithstanding the achievements at Edinburgh and elsewhere, the majority of provincial universities did not open their doors to women medical students until the early twentieth century, while Oxford and Cambridge waited until the inter-war years. ${ }^{9}$ In comparative terms, Britain lagged behind Europe by a considerable margin, although Scotland was somewhat ahead of England. ${ }^{10}$ Clearly though, the story of Jex-Blake et al. is by no means the last word on the subject. ${ }^{11}$

More recent history has tended to focus on the First World War as being something of a watershed, and there is considerable empirical evidence to support this view. ${ }^{12}$ When Dr Elsie Inglis volunteered her services at the outbreak of hostilities, she was told to "go and sit quietly at home, dear Lady". ${ }^{13}$ By the end of the war, however, the Women's Hospital Corps was numerically strong, politically acceptable and, by all accounts, doing sterling work in France. ${ }^{14}$ It has become common wisdom that the war transformed the status of women in society, ${ }^{15}$ and made possible much of subsequent feminism. ${ }^{16}$

However, even this perspective has become questionable. Some historians have suggested that apparent revolutions in the status of women have been more the result of temporary convenience than lasting ideological change. ${ }^{17}$ More philosophical historians

\footnotetext{
6 This is not to suggest that feminist writers are any more prone to bias than any other kind, simply that they are no less prone either. For a reader unfamiliar with modern feminist writing, several works provide a good general introduction: Olive Banks, Faces of feminism: a study of feminism as a social movement, Oxford, Basil Blackwell, 1986; Les Garner, Stepping stones to women's liberty: feminist ideas in the women's suffrage movement, 1900-1918, London, Heinemann Educational, 1984; Brian Harrison, Separate spheres: the opposition to women's suffrage in Britain, London, Croom Helm, 1978; Richard J Evans, The feminists: women's emancipation movements in Europe, America and Australasia, 1840-1920, London, Croom Helm, 1977.

7 The idea of unbiased history as oxymoron is cogently argued by E H Carr, What is history?, 2nd ed., edited by R W Davies, London, Penguin, 1987. See also, Isaiah Berlin, 'Political ideas in the twentieth century', in idem, Four essays on liberty, Oxford University Press, 1969, pp. 1-5.

${ }^{8}$ Geoffrey Marks and William K Beatty, Women in white, New York, Charles Scribner's Sons, 1972, sometimes gives this impression.

9 Carol Dyhouse, No distinction of sex?: women in British universities, 1870-1939, London, UCL Press, 1994, p. 157.

${ }^{10}$ Thomas N Bonner, To the ends of the earth: women's search for education in medicine, Cambridge, Mass., Harvard University Press, 1992, p. 13.

11 Mary Roth Walsh, "Doctors wanted, no women need apply": sexual barriers in the medical
}

profession, 1835-1975, New Haven, Yale University Press, 1977, makes this point in an American context.

12 A good general account with this theme is David Mitchell, Women on the warpath: the story of the women of the First World War, London, Jonathan Cape, 1966.

${ }^{13}$ Hilary Bourdillon, Women as healers: a history of women and medicine, Cambridge University Press, 1988, p. 40. Also, Mitchell, op. cit., note 12 above, pp. 177-87.

14 Flora Murray, Women as army surgeons: being the history of the Women's Hospital Corps in Paris, Wimereux and Endell Street, London, Hodder and Stoughton, 1920.

15 Vera Brittain, Lady into woman: a history of women from Victoria to Elizabeth II, London, Andrew Dakers, 1953, pp. 183-201, tends to support this view.

16 Pamela Horn, Women in the 1920s, Alan Sutton, 1995, ch. 1, takes this line of attack.

17 Sally Alexander, 'Women's work in nineteenthcentury London: a study of the years 1820-50', in Juliet Mitchell and Ann Oakley (eds), The rights and wrongs of women, London, Penguin, 1976, pp. 59-111, broaches this prospect from a Marxist angle with reference to the early nineteenth century. The notion is extended to the First World War by Penny Summerfield, 'Women and war in the twentieth century', in June Purvis (ed.), Women's history: Britain, 1850-1945, an introduction, London, UCL Press, 1995, pp. 307-32. 


\section{James Stuart Garner}

have even suggested that male suzerainty is inherent in the very language of sexual discourse. ${ }^{18}$ Modern accounts of women and medicine, especially those that focus on the early part of the twentieth century, have only begun to realize the complexity of their subject, ${ }^{19}$ and to appreciate that the appearance of liberation sometimes belies a more cynical reality. This paper is an account of one such episode.

\section{The Admission of Women Medical Students to the University of London}

In 1945, University of London policy obliged each of the London medical schools to admit a minimum quota of women amounting to 15 per cent of the total entry. ${ }^{20}$ It was not until the late 1960s that this policy was discarded in favour of more meritocratic selection criteria. ${ }^{21}$ For a number of the London schools, however, this was not their first experience of female students. Some three decades previously, seven of the twelve London schools decided to admit women on a temporary basis in light of the extraordinary exigencies of the First World War, making these institutions distinctive for having admitted women to their course twice during their history. ${ }^{22}$ Among the participants in this trial run were St Mary's, Charing Cross, St George's, Westminster, The London, King's College, and University College Hospital (UCH) medical schools. Only St Bartholomew's, St Thomas's, Guy's and the Middlesex refused to accept any women at all (see Table 1). ${ }^{23}$

I have chosen to focus here, for the most part, on St Mary's Hospital Medical School, ${ }^{24}$ partly because it was the pioneer, and therefore the prototype for subsequent schools, partly because of its substantial archive holdings, and partly to show how the episode affected an individual establishment. ${ }^{25}$ At St Mary's, this period was referred to as the "great experiment" and this paper attempts to examine whether the experiment was a success or a failure.

\footnotetext{
${ }^{18}$ Ivan Illich, Gender, London, Marion Boyars, 1983, describes the replacement of vernacular gender with biological sex, which he considers a precondition for the rise of capitalism. Sexism, in other words, is a side-effect of economics. The same idea is developed by Michel Foucault in The history of sexuality, vol. 1 , an introduction, transl. Robert Hurley, London, Penguin Books, 1990 (original French ed. Histoire de la sexualité I, La volonté de savoir, Paris, Gallimard, 1976).

${ }^{19}$ A superlative example of modern scholarship is Mary Ann Elston, 'Women doctors in the British health services: a sociological study of their careers and opportunities', PhD thesis, Leeds University, 1987.

${ }^{20}$ Report of the Special Committee of the University of London to Consider the Medical Education of Women in London, University of London, 1944.

${ }^{21}$ B R Bewley, 'Women doctors: a review', J. $R$. Soc. Med., 1995, 88: 399P-405P.

${ }_{22}$ Moberly Bell, op. cit., note 1 above, pp. 170-1.
}

\footnotetext{
${ }^{23}$ Report of the Special Committee of the University of London, op. cit., note 20 above.

${ }^{24}$ For a more general history of this establishment see Sir Zachary Cope, The history of St. Mary's Hospital Medical School: or, a century of medical education, London, William Heinemann, 1954. A more recent, briefer account may be found in Anne Barrett and Kevin Brown (eds), St. Mary's Hospital Medical School: an historical anthology, London, Imperial College and St Mary's Hospital Medical School Archives, 1990. A good starting point for the background to the London teaching hospitals, albeit with a slightly political bent, is Geoffrey Rivett, The development of the London hospital system, 1823-1982, London, King Edward's Hospital Fund for London, 1986.

${ }^{25}$ Previous studies of women's education include Mabel Phythian Tylecote, The education of women at Manchester University, 1883-1933, Manchester University Press, 1941, and, more recently, Wendy Alexander, First ladies of medicine, University of Glasgow, Wellcome Unit, 1987.
} 
Women Students at St Mary's Hospital Medical School

Table 1

Chronology of Women's Medical Education in London, 1916-1929

\begin{tabular}{|c|c|c|}
\hline $\begin{array}{l}1917 \\
1918\end{array}$ & $\begin{array}{l}\text { St Mary's } \\
\text { Charing Cross } \\
\text { St George's } \\
\text { Westminster } \\
\text { London } \\
\text { King's College } \\
\text { University College }\end{array}$ & $\begin{array}{l}\text { admits women to clinical course but only from LSMW } \\
\text { admits women "on the same terms as men" } \\
\text { admits a maximum of } 10 \text { women for the duration of the war } \\
\text { decides to admit women students } \\
\text { admits women "on the same terms as men" } \\
\text { decides to admit women students } \\
\text { decides to admit women students }\end{array}$ \\
\hline $\begin{array}{l}1919 \\
1921 \\
1924 \\
1928\end{array}$ & $\begin{array}{l}\text { St George's } \\
\text { London } \\
\text { St Mary's } \\
\text { Westminster } \\
\text { Charing Cross } \\
\text { King's College }\end{array}$ & $\begin{array}{l}\text { ceases to admit any further women students } \\
\text { ceases to admit any further women students } \\
\text { ceases to admit any further women students, effective } 1925 \\
\text { ceases to admit any further women students } \\
\text { ceases to admit any further women students } \\
\text { ceases to admit any further women students }\end{array}$ \\
\hline
\end{tabular}

\section{Before the War}

In 1914, St Mary's Hospital Medical School celebrated its sixtieth birthday having managed to avoid the issue of female students more or less entirely. For example, when Sophia Jex-Blake applied for admission in 1869, her application was peremptorily declined. ${ }^{26}$ She later secured admission to Edinburgh, together with six like-minded colleagues. ${ }^{27}$ Another prospective female student was similarly turned down in $1906 .{ }^{28}$ These periodic rejections served to remind putative women students that they would not be welcome, and further applications were scarce.

St Mary's attitude towards women was not particularly enlightened in other respects. The Students' Club Dining Room, for instance, had employed waitresses since 1907, but the caterer, Mr Pocock, justified their recruitment by explaining that "patrons of the club do not feel under the same obligation to tip a waitress as they do a waiter". ${ }^{29}$ The consequent economies would, he felt, help to replenish the dwindling patronage of his club. And in 1914, the suggested appointment of a female physiology demonstrator led the Medical School Committee to resolve that it was "inadvisable that a woman should hold a teaching post in the medical school" ${ }^{30}$ It seems likely that many of the students themselves were by no means supporters of female emancipation. In 1907, for instance, a meeting of the London Society for Women's Suffrage at Paddington Baths was alleged to have been disrupted by a squad of St Mary's students. ${ }^{31}$ It was possible then for a student

\footnotetext{
26 St Mary's Hospital Medical School Committee Minutes (hereafter Committee Minutes), entry dated 22/6/1869, 1: 367, held at the St Mary's Hospital and Medical School Archives (hereafter SMHMS Archives): MS/AD1/1.

27 Margaret Todd, The life of Sophia Jex-Blake, London, Macmillan, 1918, p. 261.

28 Committee Minutes, entry dated 18/7/1906, 4: 145 (SMHMS Archives: MS/AD1/4).
}

\footnotetext{
29 St Mary's Hospital Medical School SubCommittee Minutes (hereafter Sub-Committee Minutes), entry dated 25/11/1907, 1: 50 (SMHMS Archives: MS/AD5/1).

30 Committee Minutes, entry dated 6/10/1914, 4: 456 (SMHMS Archives: MS/AD1/5).

31 Committee Minutes, entry dated 17/12/1907, 4: 253 (SMHMS Archives: MS/AD1/4).
} 


\section{James Stuart Garner}

to re-take his examinations an unlimited number of times, remaining in the school so long as his funds permitted, and there were often a number of veteran students of advancing age whose waking hours were devoted in chief measure to perpetrating these sort of escapades. $^{32}$

It would certainly be a mistake to claim that these incidents were unique to St Mary's, or even to London. The position of the female medical student in this period was likely to be somewhat fraught wherever she chose to study, but the determination with which the London schools avoided women students was something singular. In few other parts of England, or indeed Europe, did women meet such concerted resistance. In explaining this phenomenon, it would be inadequate to portray places like St Mary's simply as reflections of wider cultural attitudes. By 1914, the old notions of women's sexual inferiority were beginning to fall by the intellectual wayside, while the principle of female employment was percolating upwards and swiftly through the class structure. The supposed Victorian polarization between male domination and female servitude was no longer a social constant, if indeed it ever had been. ${ }^{33}$ As far back as 1874, it had been possible for Thomas Hardy to place the female landowner, Bathsheba Everdene, in a position of social, economic and sexual superiority over the hapless farmer Gabriel Oak. ${ }^{34}$

The medical profession and the academic institutions were also gradually coming round to a more liberal position. The British Medical Association, for example, had started admitting women members in 1892, although Elizabeth Garrett Anderson, with characteristic precocity, had managed to secure admission some nineteen years previously. ${ }^{35}$ One of her two sponsors was from St Mary's Hospital. ${ }^{36}$ London University had been among the first in the country to open its degrees to women in 1878, although, in practice, the decision to accept women onto a medical course remained the prerogative of individual schools. It would be unjust to attribute this reluctance to simple malevolence on the part of individual doctors and educators. On the contrary, several members of the Medical School Committee were of decidedly liberal temperament, and there existed a long history of informal co-operation between St Mary's and the London School of Medicine for Women (LSMW). ${ }^{37}$ The first dean of the latter establishment was a St Mary's surgeon named Arthur Norton, ${ }^{38}$ who had been a member of the Medical School Committee at the time of Sophia Jex-Blake's rejection in $1869 .{ }^{39}$ Many of his colleagues, moreover, taught at the LSMW in a private capacity. ${ }^{40}$ In 1915 , the Chairman of the Hospital Board of Management, Mr Austin Leigh, "stated that he was in favour of the

\footnotetext{
32 The type is parodied in Charles Dickens, The Pickwick papers, first published 1836-37, see Oxford Press edition, 1988, p. 366. Although Dickens was long dead by this time, his caricature remained largely accurate.

${ }^{33}$ Foucault is sceptical about this "repressive hypothesis", op. cit., note 18 above, pp. 3-13. 1874.

34 Thomas Hardy, Far from the madding crowd,

${ }^{35}$ Lutzker, op. cit., note 3 above, pp. 116-17. Before Elizabeth Garrett Anderson's admission, the BMA charter contained no mention of women, and it was through this loophole that she was able to enter.
}

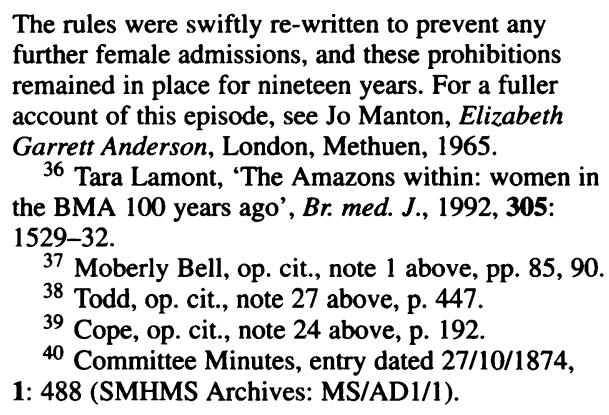
further female admissions, and these prohibitions remained in place for nineteen years. For a fuller account of this episode, see Jo Manton, Elizabeth Garrett Anderson, London, Methuen, 1965.

${ }^{36}$ Tara Lamont, 'The Amazons within: women in the BMA 100 years ago', Br. med. J., 1992, 305: 1529-32.

${ }_{37}$ Moberly Bell, op. cit., note 1 above, pp. 85, 90.

38 Todd, op. cit., note 27 above, p. 447.

39 Cope, op. cit., note 24 above, p. 192.

40 Committee Minutes, entry dated 27/10/1874, 1: 488 (SMHMS Archives: MS/AD1/1). 


\section{Women Students at St Mary's Hospital Medical School}

admission of women students to the school", ${ }^{41}$ and it may reasonably be supposed that he would have been backed by Dr Graham Little, who later became MP for the University of London, and who is recorded by Munk's Roll as being an ardent supporter of women's medical education. ${ }^{42} \mathrm{Mr}$ Zachary Cope, a well-respected surgeon with considerable influence in the school, had publicly expressed his own support of women's medical education several years previously. The opinions of a Dr R H Miller are not recorded, but he later married one of the first intake of female students, so a benevolent attitude on his part seems plausible. ${ }^{43}$ Meanwhile, Dr Alcock, head of the physiology department, had tried on numerous occasions and with admirable pertinacity to introduce women students into St Mary's without success. ${ }^{44}$

A sense of tolerance is also suggested by the outcome of a debate staged in 1910 by the St Mary's Medical Society, concerning 'The medical aspects of women's suffrage'. On one side, George Bernard Shaw supported female emancipation in all its forms, while on the other, Sir Almroth Wright rejected it. Although the vote came down in Sir Almroth's favour, an account in the St. Mary's Hospital Gazette notes that it was "a near thing" 45 If almost half the audience agreed with Shaw, it seems clear that St Mary's sexist disposition was far from total.

St Mary's presents the paradox of an establishment tenaciously resistant to women students, many of whose members were in fact remarkably progressive. The situation was much the same in the rest of London. ${ }^{46}$ In 1914, the only college providing medical education for women in London was the LSMW for pre-clinical teaching, associated with the Royal Free for clinical experience. Part of the problem was undoubtedly the city itself. Although an upstanding middle-class family could dispatch its daughters to Edinburgh or even Liverpool without undue concern, the thought of young ladies roaming the scrofulous streets of London unprotected was offensive to Edwardian sensibilities. Many Londoners of the period would have sympathized with Shelley's observation that "Hell is a city much like London". ${ }^{47}$ One of St Mary's earliest female students recalls her mother insisting that "You are too young to live in London", although she was twenty-four years old at the time. ${ }^{48}$

St Mary's geographical position was a disadvantage. Most of the London teaching hospitals had been established in areas of particular deprivation to meet the needs of impoverished working-class inhabitants. St Mary's was located in Paddington, the least salubrious sector of west London. The Great Western Railway perfused the area with disreputables and undesirables, the Grand Union Canal maintained a population of unskilled workers just above the poverty line, and Sussex Gardens was a notorious redlight district. This was hardly the place for young ladies.

More significantly, the students at the London medical schools were a class unto themselves. Whereas the provincial schools, by this stage, were almost invariably an

\footnotetext{
41 Committee Minutes, entry dated 6/12/1915, 5: 69 (SMHMS Archives: MS/AD1/5).

42 Munk's roll of the lives of the fellows of the Royal College of Physicians, 1826-1925, London, RCP, 1955, vol. 4, pp. 475-6.

43 Ibid., p. 553.

44 Committee Minutes, entry dated 18/7/1906, 4: 145 (SMHMS Archives: MS/AD1/4).
}

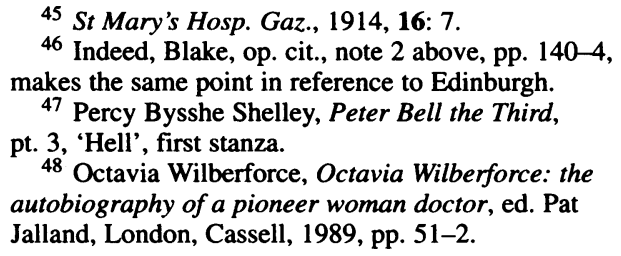

45 St Mary's Hosp. Gaz., 1914, 16: 7.

46 Indeed, Blake, op. cit., note 2 above, pp. 140-4, makes the same point in reference to Edinburgh.

${ }^{47}$ Percy Bysshe Shelley, Peter Bell the Third, pt. 3, 'Hell', first stanza.

48 Octavia Wilberforce, Octavia Wilberforce: the autobiography of a pioneer woman doctor, ed. Pat Jalland, London, Cassell, 1989, pp. 51-2. 
integral part of their parent universities, the London schools were comparatively freestanding and the medical students were present in undiluted concentration. There were no upright lawyers, sensitive students of English, or insightful scholars of philosophy at places like St Mary's. Only here did the hard-drinking, hard-living, rugby-playing, publicschool educated medic achieve ubiquity, with all his attendant machismo and preposterous ritual. The library was used as a boxing club on two nights a week, testifying both to the relative priorities of sport and reading, and to the emphatically masculine atmosphere within the school. ${ }^{49}$ Neither the medical schools nor the families of potential female students were prepared to risk the consequences of immersing their daughters in this strange environment, the elder brother of the Edwardian public school. ${ }^{50}$ But perhaps most important of all, the financial circumstances of the London schools were always precarious. Unlike the provincial schools, whose financial oscillations could be absorbed and dissipated throughout their parent universities, the London schools were run as going concerns, subject to the cruel vicissitudes of a cut-throat market place. They bought their political autonomy at the price of financial security. A few fallow years could close a medical school and so a policy of caution seemed the best hope for survival. St Mary's was especially wary, having come to the edge of bankruptcy around the turn of the century, as a result of a financial scandal which left the school some $£ 2,600$ in debt. ${ }^{51}$ Innovation was not the order of the day, and maintenance of the status quo took precedence over the diaphanous whims of liberal affectation.

In 1914, therefore, the walls of London circumscribed one of the last bastions of singlesex medical education. How then were women to storm this citadel?

\section{The Great War}

The outbreak of war in 1914 had several immediate consequences for St Mary's. ${ }^{52}$ On the whole, both hospital and medical school were quick to enter into the spirit of things. Teaching was provided gratis for the RAMC, a third of the hospital beds were set aside for casualties, ${ }^{53}$ and Sir Almroth Wright's typhoid vaccine was employed to the benefit of the troops. ${ }^{54}$

Many of the medical and administrative staff were quick to volunteer; the physiology lecturer and the chemistry demonstrator were among the first to go, and they were followed in quick succession by the Commissionaire and the School Secretary's Clerk. ${ }^{55}$ Twenty-five of the nursing staff left for foreign service and seven for home duties, a trend

49 Committee Minutes, entry dated 5/3/1909, 4: 319 (SMHMS Archives: MS/AD1/4).

${ }^{50}$ Even the redoubtable Sophia Jex-Blake had found this prospect unnerving twenty-five years earlier, op. cit., note 5 above, pp. 156-7.

51 Committee-Minutes, entry dated 14/3/1900, 3: 210 (SMHMS Archives: MS/AD1/3).

52 An interesting essay which explores the consequences of the First World War for women at large is Françoise Thébaud, 'The Great War and the triumph of sexual division', transl. Arthur Goldhammer, in Georges Duby and Michelle Perrot (eds), A history of women in the west, vol. 5,
Towards a cultural identity in the twentieth century, Cambridge, Mass., Belknap Press of Harvard University, 1994, pp. 21-75. Thébaud is one of several recent historians to cast doubt on the liberating effects of the First World War.

53 'St. Mary's and the War', St. Mary's Hosp. Gaz., 1914, 20: 113.

54 A fact loudly trumpeted in A hospital which has accomplished something new!, a fund-raising pamphlet from the mid-1920s (SMHMS Archives: SM/MX4/15).

55 Committee Minutes, entries dated 6/10/1914 to 4/5/1915, 5: 16-49 (SMHMS Archives: MS/AD1/5). 


\section{Women Students at St Mary's Hospital Medical School}

mirrored in most of the London hospitals. ${ }^{56}$ Across the country the shortage of nurses led to a rapid influx of upper- and middle-class ladies on a volunteer basis, whose achievements precipitated a popular realization that women could tend the suffering without sacrificing either their femininity or their respectability. One of the most illustrious volunteers at St Mary's was Princess Arthur of Connaught, grand-daughter of Edward VII, whose service from 1915 to 1918 gave the hospital the distinction of having trained the first member of the Royal Family to become a State Registered Nurse. ${ }^{57}$

Many of the doctors also took their commission, nearly all the housemen volunteered, ${ }^{58}$ and so acute was the deficit that, in some cases, students were required to fill their places, notwithstanding their lack of qualifications-a fact which occasioned some concern among members of the Hospital Board. ${ }^{59}$ Most significant of all, students themselves were to prove increasingly hard to come by: new admissions plummeted and many current students left mid-way through their studies in order to pursue greater glories at the Somme. St Mary's could certainly no longer afford to be too precious about the students it admitted. Indeed, in 1915, a Mr August Alfred Appelt, a non-naturalized German, was admitted to the first MB course ${ }^{60}$ The implications of this are sobering: at the height of the First World War, St Mary's was admitting Germans in preference to women.

For those students who remained, St Mary's became a more sober establishment, and the corridors of the medical school were gloomy and hushed. The St Mary's Hospital Gazette remarked on the alteration: "The raucous notes of the adolescent male are fast disappearing from within our walls, and we pen these lines in the midst of a most melancholy silence". ${ }^{61}$ Worse still, the rugby team was all but extinguished in this period, and contemporary issues of the Gazette often bemoaned the difficulty of organizing matches when the players of both sides were subject to call-up and the pitch was requisitioned for military exercises. ${ }^{62}$

From an administrative standpoint, however, the financial impact was much more significant. Subscriptions to the hospital had been drying up for some time, largely on account of the agricultural revolution having lowered the value of land, but the war brought extra outgoings and further reductions in income. Each of the absent staff members had their positions held open pending their return, and in many cases their salaries continued to be paid to their relatives. Services and products that would normally have been charged for, such as Almroth Wright's typhoid vaccine, were altruistically donated to the war effort, depriving St Mary's of income. And most serious of all, new admissions to the school dwindled almost daily, slashing its principal source of revenue. By late 1915, the current account was overdrawn by more than $£ 1,000$ and the school found itself sinking into bankruptcy. ${ }^{63}$

In December 1915, a state of crisis was reached and a Sub-Committee was appointed to consider how best to resuscitate the school. The budgetary axe was wielded with

\footnotetext{
56 Kevin Brown, 'Another day, another war', St. Mary's Hosp. Gaz., 1991, 97 (2): 35-7.

57 Idem, 'Contact with the seamy side of life', St. Mary's Hosp. Gaz., 1990, 96 (3): 38-9.

58 'St. Mary's and the war', St. Mary's Hosp. Gaz., 1914, 20: 113.

59 Committee Minutes, entry dated 2/2/1915,
}

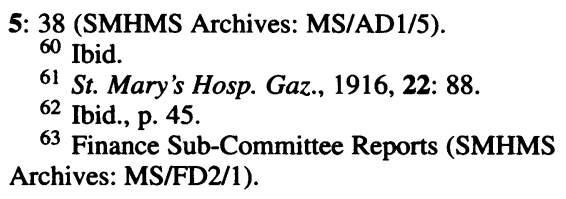




\section{James Stuart Garner}

merciless abandon, and each department was cut to the bone. But even these Draconian measures were not sufficient:

In all, the proposed reductions amount to a sum of $£ 790.10 .11$ and if these be resolved upon, the estimated expenditure for 1916 would amount to $£ 3572.9 .0$ against estimated receipts of $£ 3203.14 .9$ showing a cash deficit of $£ 368.14 .4{ }^{64}$

The possibility of abolishing preliminary scientific teaching was given a brief airing, but was swiftly jettisoned when it was realized that over half the new students entered the school at this level, and the loss of such teaching would be likely to deplete admissions further still. The Sub-Committee concluded that the only option remaining was for the school to begin admitting women students.

The Medical School Committee baulked at the prospect and decided instead to impose a compulsory donation of $£ 20$ on each member of staff. This was probably neither the first nor the last time it fell to the staff to shore up their medical school, and possibly they welcomed the opportunity to demonstrate their loyalty, but they could not be relied upon to subsidize St Mary's indefinitely. A more durable source of income was urgently required. By early 1916, the realization dawned that the admission of women students might be the only hope for survival. Thus, tentative negotiations were entered into with the LSMW, and an agreement was finally reached in which the LSMW was to supply fifty female students to St Mary's for clinical teaching by October 1917, at a fee of $£ 21$ per student per annum. The pact was subject to re-negotiation in September 1919, and thereafter at a year's notice. ${ }^{65}$

This arrangement was certainly of mutual advantage. The limited teaching capacity of the Royal Free Hospital had been causing something of a bottleneck for the LSMW, and the opportunity to send a proportion of the students elsewhere was welcomed as a way of increasing the school's output. For St Mary's, the acquisition of a stable supply of new students offered the only practical way to maintain solvency. Even the restriction to clinical teaching was mutually beneficial. The LSMW already had substantial pre-clinical capacity, and had no desire to sub-contract this task out to St Mary's. Conversely, St Mary's was reluctant to admit women to the pre-clinical course, since it would then be involved in a five-year commitment, even if the experiment should prove detrimental. It is important to realize what this was and what it was not. That neither institution was acting out of altruism was clear from the outset, nor was this a spontaneous recognition of women's rights on the part of St Mary's. Rather, it was a temporary convergence of disparate interests, in which the female students themselves were merely a commodity to be bartered according to convenience.

Structural alterations began immediately. The old biological laboratories were hastily converted into a ladies common room $(37 \mathrm{ft}$ x $17 \mathrm{ft}$ ), cloakroom and lavatory ( $37 \mathrm{ft} \mathrm{x} 10$ $\mathrm{ft})$ at a cost of some $£ 175 .{ }^{66}$ In April 1916, the St Mary's Hospital Gazette cast an approving eye over the proceedings:

64 Report of Staff Sub-Committee upon economies to be effected during the war and upon the proposal to admit women students, dated 29/11/1915 (SMHMS Archives: MS/AD44/1).
${ }^{65}$ Sub-Committee Minutes, entry dated 2/3/1916

(SMHMS Archives: MS/AD5/2).

66 Committee Minutes, entry dated 7/3/1916, 5: 82 (SMHMS Archives: MS/AD1/5). 


\section{Women Students at St Mary's Hospital Medical School}

The old Biology laboratory is no more; not a trace of that odour of decaying dogfish which gave the old room such a homey feeling now clings to its walls. The benches have been removed, a solid partition wall has sprung up as if by magic, and we have a commodious common room with a cloakroom, h. and c. laid on, opening out of it. ${ }^{67}$

The first batch of twelve women students began work on 1 May $1916 .{ }^{68}$ The Gazette was there to count them in, but took pains to play down their significance:

It must not be supposed, however, that the school has been thrown open to women in the same way as it is to men; this is far from being the case, and it is not proposed to do more than offer temporary accommodation to the overflow from the Royal Free Hospital. ${ }^{69}$

It is amusing now to read the event portrayed in terms of institutional gallantry: as if St Mary's was merely assisting the LSMW by temporarily putting up its surplus students. But despite the somewhat clumsy propaganda, nobody could be unaware that this was a pivotal movement in St Mary's history. The Gazette conceded the obvious with an evocative touch of rhetoric: "it is no use pretending that this is not a revolutionary step to take ... It is plain that we are entering upon a great experiment, one which may be a brilliant success or a lamentable failure; there is no other possibility". ${ }^{0}$

\section{The Impact of the Women Students}

Of the women themselves, several observations are worth making. First, they were not significantly older than their male colleagues. Between 1916 and 1918, the average age on admission was twenty-four for the male students and twenty-six for the female students. ${ }^{71}$ Since the women students had already complete their pre-clinical training at the LSMW, which lasted two years, the students in any given year were actually about the same age. These averages seem high given that most students on admission were eighteen or nineteen, but the addition of a few individuals in their thirties, and even one or two in their forties, raised the mean by a few years.

From an academic standpoint, the women students were undeniably brighter than the men. Although an examination of school prizes shows the men to be superior, ${ }^{72}$ such an analysis ignores the fact that women were ineligible for pre-clinical prizes, having completed that section of their course at the LSMW. More representative is a study of examination results, which shows a higher proportion of women achieving the prestigious London degree (MB, BS), and fewer failing to qualify (see Table 2). ${ }^{73}$ In her autobiography, Ida Mann, one of the 1917 entry, explained this trend:

The first batch of women to St. Mary's were chosen for their intelligence, ambition and academic record. They were supposed to create a good impression among the male students. Of course these were horrified. All the keen young men had escaped to the War and only the lame ducks, the persistent failers at exams and the elderly men students were left. The girls were so clever, worked

${ }^{67}$ St. Mary's Hosp. Gaz., 1916, 22: 47.

68 Committee Minutes, entry dated 1/5/1916,

5: 84 (SMHMS Archives: MS/AD1/5).

69 'Place aux dames', St. Mary's Hosp. Gaz., 1916, 22: 41.

70 Ibid.

71 These figures are based on computer analysis

of Student Record Cards (SMHMS Archives: MS/AD28/1-2207). A card was maintained for each student, and they contain various details including date of birth and date of admission.

72 Ibid.

73 Ibid. 


\section{James Stuart Garner}

\section{Table 2}

Examination Results at St Mary's Hospital Medical School, 1916-1918

\begin{tabular}{lrcrr} 
& \multicolumn{2}{c}{ Men } & \multicolumn{2}{c}{ Women } \\
\hline MB, BS & 6 & $15 \%$ & 38 & $49 \%$ \\
LRCS, MRDP & 20 & $50 \%$ & 28 & $36 \%$ \\
LMSSA & 3 & $7.5 \%$ & 2 & $3 \%$ \\
No qualification & 11 & $27.5 \%$ & 9 & $12 \%$ \\
Total & 40 & $100 \%$ & 77 & $100 \%$ \\
\hline
\end{tabular}

so hard, were no good at rugger, didn't want to indulge in sport, even of the bedroom variety, and were a dead loss all round. Indeed they rather showed up everyone's inefficiency. ${ }^{74}$

Outside the examination hall, the women students breathed new life into St Mary's. Most striking was the increase in the size of the school (see Figure 1). ${ }^{75}$ From an annual

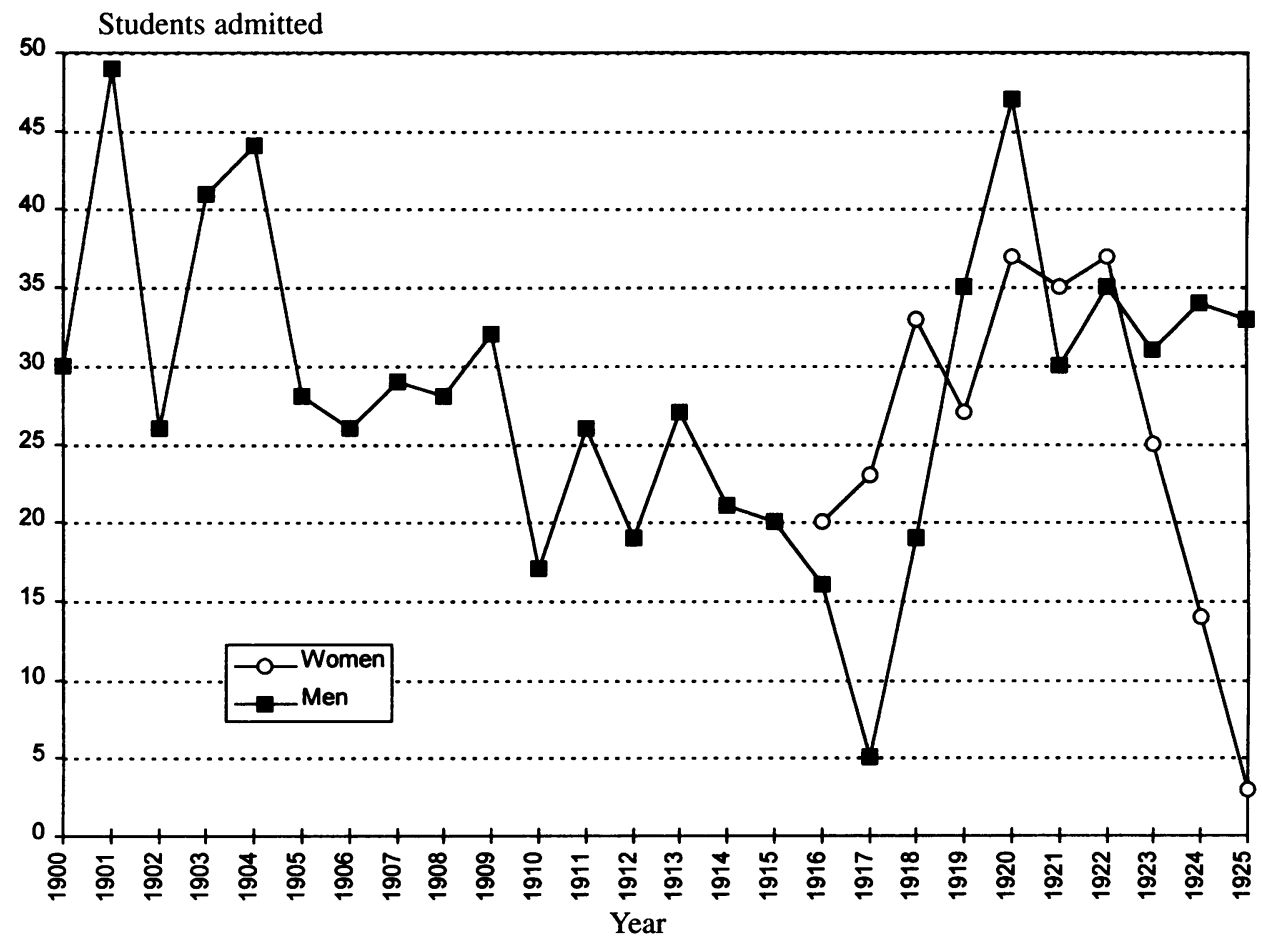

Figure 1: Annual admissions to St Mary's Hospital Medical School, 1900-1925

${ }^{74}$ Ida Mann, MS of autobiography, p. 126 (SMHMS Archives: DP21). This autobiography was later published as The chase: an autobiography, ed. Ros Golding, Fremantle Arts Centre Press, 1986. The MS was substantially edited before publication, and that part of its contents referring to St Mary's was largely excised. For this reason, I have used the MS version on two of the three occasions in which I refer to Professor Mann's work.

75 'Annual entry of students since the beginning of the Medical School', loose-leaf document (SMHMS Archives: MS/AD39/1). 


\section{Women Students at St Mary's Hospital Medical School}

intake of about twenty students, St Mary's found itself in 1918 catering to fifty or more. A cohort effect meant that the hospital also benefited in due course, as the women graduated and assumed resident posts therein. ${ }^{76}$

However, the financial consequences were of much more interest to the school. Here the improvements were less breathtaking: the women certainly brought about an upturn in St Mary's fortunes but the school did not realize overnight prosperity. Not until 1918 did the current account balance creep back into the black. ${ }^{77}$ Nevertheless, it seems clear that the extra revenue from the women students did save the school from almost certain bankruptcy, but through gradual convalescence rather than a miracle cure.

The women also brought subtler changes. In 1918, Miss Macatta commenced dancing lessons for male and female students in the library, where they soon usurped the lapsed boxing club. ${ }^{78}$ Indeed such atavistic recreations seemed altogether passé when compared to Miss Pam's intriguing 1917 lecture on 'Artificially contracted heads'. ${ }^{79}$ by 1922 , St Mary's found itself in possession of a Musical and Dramatic Society, of which half the ten committee members were female. ${ }^{80}$ In a relatively short space of time, the women students began the Herculean task of introducing culture to St Mary's.

In the initial stages, though, the women's reception was cautious. The Gazette ruminated on the matter at length, adopting a curiously anthropological line of reasoning:

In all primitive communities the separation of the sexes during the period of adolescence is rigidly enforced. Each community has its own particular customs, but the essentials are the same the world over. The adolescent youth is taken apart from the women and placed under the care of the Elders, who instruct him in the traditional rites and mysteries, thus preparing him for the assumptions of the responsibilities of manhood in the councils and the activities of the tribe. ${ }^{81}$

Despite these reservations, however, St Mary's endeavoured to accommodate the women as satisfactorily as circumstances would permit. Their efforts were not in vain. For example, Miss Lloyd-Williams, an appreciative student, wrote in the Gazette: "One cannot too gratefully acknowledge the care and forethought evidently displayed in making us comfortable. The Common Room, with its scheme of rose-pink, white enamel and looking-glasses is, we feel, a touching and delicate attempt to please the feminine taste". 82

Such professions of goodwill soon overcame much of the initial trepidation, and the Gazette found itself extending a laudatory olive branch:

Our new guests from the London School of Medicine for Women have, of course, already settled down as medical students, and it only remains for us to assure them that at St. Mary's they will find a warm welcome. The pioneers of last May have brushed away any doubts as to the success in the experiment of co-education, which even the most old-fashioned among us might have cherished, and the wisdom of the step has been triumphantly demonstrated. ${ }^{83}$

76 Leah Leneman, 'Medical women at war, 1914-1918', Med. Hist., 1994, 38: 160-77, takes a dim view of the women's job prospects after qualification. At St Mary's, however, the positions of house physician and house surgeon, at least, were available on an egalitarian basis.

77 Finance Sub-Committee Reports (SMHMS Archives: SM/FD2/1).

78 Committee Minutes, entry dated 3/12/1918, 5: 189 (SMHMS Archives: MS/AD1/5).

\footnotetext{
79 'On artificially contracted heads', St. Mary's Hosp. Gaz., 1917, 23: 29.

80 'St. Mary's Musical and Dramatic Society', St. Mary's Hosp. Gaz., 1922, $28: 21$.

81 'Co-education at St. Mary's', St. Mary's Hosp. Gaz., 1916, 22: 16

82 'First impressions', in ibid, p. 80.

83 'A word in season', in ibid, p. 97.
} 


\section{James Stuart Garner}

The school made it a point of policy to treat its female students on the same terms as the men. For example, when, in 1916, Dr Bird asked the Committee whether or not male and female students should be separated for gynaecological clerkships he was curtly informed that there was no necessity for separation of the sexes. ${ }^{84}$ Similar representations from the LSMW regarding the teaching of venereal diseases were likewise dispatched with some celerity. ${ }^{85}$ Having taken the decision to accept women, St Mary's evidently made an effort to do so wholeheartedly.

St Mary's relationship with the LSMW, however, was several degrees cooler, and a number of petulant squabbles quickly divided the two schools. In October 1916, St Mary's requested that the LSMW contribute to the cost of heating and lighting in the school. The latter offered $£ 20$ to cover these utilities on a goodwill basis. Thus encouraged, St Mary's went on to announce that the female students would be subject to a Path. Chem. Fee of $£ 1$. 11s. 6d. per student. The LSMW contested this claim and won, but institutional harmony was already damaged beyond repair. The mercenary tone of these transactions reveals St Mary's increasing self-confidence with respect to co-education. By all accounts, the school was adapting well, revenue was increasing year by year, and the arrangement with the LSMW was beginning to seem more like hindrance than assistance. It limited the number of women in the school to fifty, it prevented St Mary's from accepting women students from another source, and it disbarred women from the pre-clinical course at $\mathrm{St}$ Mary's. In October 1919, under the terms of their original agreement, St Mary's served notice upon the LSMW that the pact would terminate, with effect from September 1920.

However, the women students themselves continued to be regarded in a benevolent light. By the time the first intake of women students graduated, the "great experiment" had been pronounced a success. In the Dean's Report for 1915-1918, Sir John Broadbent, then the incumbent of that post, summarized the first three years of co-education:

Owing to the great reduction in the number of male students as a result of the Army Council regulations calling up all men of military age, the Authorities decided, on being approached by the London School of Medicine for Women, to enter into an arrangement for the admission of women students from that school for the clinical portion of their curriculum (viz. 4th, 5th and 6th years).

The first group of these students began work in May 1916 and the arrangement has proved very satisfactory.

There was no friction of any kind and the women students ably filled the posts of Dressers and Clinical Clerks in the Wards. Subsequently, they were very successful in examinations and, since qualification, many have held resident posts in the hospital as House Physicians and House Surgeons. ${ }^{86}$

Although Sir John's positive gloss may be a little over-enthusiastic, the sense of achievement is by no means unwarranted. Only four years after the onset of the great experiment, fully egalitarian co-education had been ushered into St Mary's. And by then, many of the other London medical schools had also begun accepting female students, encouraged by St Mary's example. By the end of 1918, seven of the twelve London schools were admitting women to some extent, most of them on the same terms as men. ${ }^{87}$

84 Committee Minutes, entry dated 4/7/1916,

5: 89 (SMHMS Archives: MS/AD1/5).

85 Committee Minutes, entry dated 6/2/1917,

5: 112 (SMHMS Archives: MS/AD1/5).

\footnotetext{
${ }^{86}$ St Mary's Hospital Medical School Prospectus, 1918.

${ }^{87}$ Report of the Special Committee of the University of London, op. cit., note 20 above.
} 
It seemed as though London's bachelor days were over, and Metropolitan women medical students had the luxury of choice at last. But clouds were on the horizon.

\section{After the War}

The Armistice of 11 November 1918 brought the Great War to its conclusion. After almost four years, the troops began returning home to a Britain very different from the one they had left. ${ }^{88}$ For the universities, the conclusion of hostilities was marked by a sudden deluge of male students, but of a different sort than before. These men were roughened by the trenches, hardened by the horrors of war, and rendered self-confident by the exercise of authority. In some universities, particularly Oxbridge, traditional discipline all but collapsed. $^{89}$

At St Mary's, the 1920 intake reached a record eighty-four admissions, of which thirtyseven were women. Although this influx brought great prosperity to the medical school, discipline took a sharp turn for the worse, here as elsewhere. For example, the Medical School Committee found itself considering the case of Mr K J M Graham, a third-year student, of whom it was alleged that he "had been guilty of serious misbehaviour at the Cup Tie Match (Rugby Football) between St Mary's and Guy's on 5th Feb. 1920, having been very drunk while upon the field". 90

These returning heroes reacted very differently to the women students than their noncombatant peers, and a sense of distrustful stand-off soon became evident. It is easy to imagine the intrinsic incompatibility between these drunken rugby-playing ex-servicemen and the women with their "touching and delicate scheme of rose-pink and white enamel". Worst of all, some of the women were by now serving as demonstrators or house officers, which placed them in positions of authority over the men. One recalcitrant male student is recorded as having berated his female demonstrator thus: "Damn and blast you. Look, five days ago I was killing Germans. How the hell can you expect me to spend the afternoon tying little bits of cotton and wire to a dead frog?"91

Discord began to ferment. As early as May 1919, one of the male students wrote a letter to the St. Mary's Hospital Gazette blaming the women students for the low male attendance at clinical teaching. He explained that he and his colleagues were bashful at the prospect of being shown up in front of their female peers, and consequently chose to remain at home in bed. He accused the entire female sex of a "lack of initiative and practical ability", before proceeding to castigate them for being too polite as teachers and demonstrators:

I, for one, would much rather be sworn at than be timidly asked whether I would mind being told, etc. etc. While I keenly remember the former, the latter is but the amusement of the minute . . . chiffon is but a poor substitute for the cat-o'-nine-tails. ${ }^{92}$

88 An excellent account of the changes wrought by the First World War can be found in Arthur Marwick, The deluge: British society and the First World War, London, Bodley Head, 1965. Of particular interest is ch. 3, which considers the effects on the social status of women. Although some of the underlying theory has been superseded by modern gender studies, this remains a very worthwhile account.
89 V H H Green, A history of Oxford University, London, B T Batsford, 1974, p. 188.

90 Committee Minutes, entry dated 2/3/1920,

5: 246 (SMHMS Archives: MS/AD1/5).

91 Ida Mann, MS of autobiography, op. cit., note 74 above, p. 154.

92 St. Mary's Hosp. Gaz., 1919, 25 : 72. 


\section{James Stuart Garner}

Whatever interest the piece may hold for a psychoanalyst, it struck a chord in St Mary's. The men were fast regaining numerical superiority, and with strength of numbers came a more bombastic attitude. The women students found themselves under fire. The admission of the women students had originally been conceived as a "temporary expedient" and circumstances were now changing out of all recognition. A late 1919 issue of the Gazette suggested it might be time to re-evaluate matters: "The period of temporary expedients is passing quickly, and it behoves us, in common with the rest of the world, to overhaul our existing conditions, and think out permanent policies." 93

It was to this atmosphere of growing discontent that two of St Mary's most illustrious members returned, crowned with the laurels of war. The first was a St Mary's-trained doctor named Charles McMoran Wilson, who succeeded Sir John Broadbent as Dean of the Medical School in December $1920 .{ }^{94}$ Wilson was later created Baron Moran of Manton for his service as Winston Churchill's personal physician. ${ }^{95}$ The institutional mythology of St Mary's remembers him to this day as "the Great Dean". But in 1920, he was still a young commoner with some very particular ideas of how a medical school should be run.

Wilson had developed his own distinctive conceptions of nobility as a result of his war experience, and had gone so far as to publish a book explaining them. ${ }^{96}$ His philosophy was somewhere between that of Baden Powell and Chairman Mao: there was a distrust of intelligence, an adulation of team sports, and a strong emphasis on service, duty and loyalty. ${ }^{97}$ In practice, Wilson most commonly found these qualities in public schooleducated rugby players, simple souls with a canine capacity for unquestioning fidelity. These then were the new recruits he sought for his medical school, and these were the raw materials with which he planned to shape his vision into practical reality. This was a time when the Ministry of Reconstruction was re-creating Britain, and Wilson dreamed of doing the same for St Mary's. There was little room for feminine sensibilities.

Also returning from France was Sir Almroth Wright, the renowned pathologist, whose vital contribution to the war had been orchestrated from his makeshift laboratories in the basement of the Boulogne casino. Wright had come to St Mary's in 1902 from the Royal Army Medical School at Netley, ${ }^{98}$ where he had developed a vaccine against typhoid, and he had proceeded to set up his department in a disused section of the Clarence Wing. ${ }^{99}$ It was the first of its kind in the UK, a semi-autonomous research facility operating in symbiosis with a parent hospital. From the comfort of this Inoculation Department, ${ }^{100}$ Wright could develop his theories of vaccine therapy, and many of the finest medical minds of the period were nurtured here. It was in the Inoculation Department, for example, that Alexander Fleming made the discovery that was to lead to penicillin. ${ }^{101}$

93 Ibid., p. 81.

94 Committee Minutes, entry dated 7/12/1920,

5: 292 (SMHMS Archives: MS/AD1/5).

95 Richard Lovell, Churchill's doctor: a biography of Lord Moran, London, Royal Society of Medicine Services, 1992, p. 197.

96 Lord Moran, The anatomy of courage, London, Constable, 1945.

97 Richard Lovell, 'Choosing people: an aspect of the life of Lord Moran (1882-1977)', Med. Hist., 1992, 36: 442-54, p. 447.

${ }^{98}$ Leonard Colebrook, Almroth Wright: provocative doctor and thinker, London, William Heinemann, 1954, p. 46.

${ }_{99}$ Sir Zachary Cope, Almroth Wright: founder of modern vaccine-therapy, London, Thomas Nelson, 1966, p. 40.

100 A good account of the Inoculation Department's inner workings can be found in Gwyn Macfarlane, Alexander Fleming: the man and the myth, London, Chatto \& Windus, 1984, pp. 59-61.

${ }^{101}$ L J Ludovici, Fleming: discoverer of penicillin, London, Andrew Dakers, 1952, pp. 131-4. 


\section{Women Students at St Mary's Hospital Medical School}

As an individual, Wright aroused strong feelings in those who met him. To some he was the epitome of eccentric genius; ${ }^{102}$ to others, a bigoted, irascible old man. His friend George Bernard Shaw based the character of Sir Colenso Ridgeon in The doctor's dilemma on Wright, who made a point of flamboyantly walking out of the first night in 1906. ${ }^{103}$ According to the contemporary fashion, Wright also turned out a book of armchair philosophy: a turgid work entitled Prolegomena to the logic which searches for truth. ${ }^{104}$ It is probably no accident that history remembers him as a pathologist rather than as a philosopher.

"The Paddington Plato" was also a notorious misogynist. He had outlined his views in 1913, in a polemic entitled The unexpurgated case against women's suffrage. ${ }^{105}$ As legend would have it, the well-known pianist, composer and feminist, Ethyl Smythe, was dispatched to throw a brick through his window by way of reply, ${ }^{106}$ but Wright continued to insist that there were "very weighty reasons why the suffrage should not be conceded to women". $107 \mathrm{He}$ proceeded to categorize supporters of the suffrage into "the intellectual", "the crank", "the complementary male", and John Stuart Mill. The latter merited special disapprobation and was described as "an unprofitable trafficker in abstractions". A contemporary female student described Wright as "a fierce, hoary lion of a man, who never spoke to a woman, who hated students of any sort, and who refused to teach except for the few statutory lectures he had to give". ${ }^{108}$ Nobody was more dismayed to find women at St Mary's than Sir Almroth, and he made it a matter of priority to employ his considerable influence in expediting their removal.

There existed, therefore, a tide of discontent against the women students, growing in magnitude for several years after the end of the First World War, and with highly vocal proponents among both the staff and the students. Matters came to a head in 1924. On April Fool's Day of that year, the Medical School Committee was presented with a petition bearing the signatures of ninety-six male students, asking that women should no longer be admitted to St Mary's. It began: "The recent, but apparently habitual defeat of St. Mary's in the Rugger Cup-tie, calls for serious consideration". ${ }^{109}$ The document is remarkable in style and content. The principle argument was that the presence of women students in St Mary's was somehow draining the school's institutional virility, and that the most conspicuous index of this decline was to be found in the rugby results. It was clearly assumed that no stronger reason could be proposed for their removal, and the petition concluded in the strongest terms: "The men do not want the women, they have no wish to be friends, or to co-operate with them in any way". 110

Despite its stylistic deficiencies, the petition evinces some forethought. It mentions rugby, esprit de corps, institutional prestige, and it even manages to include a spurious financial case. Each of these elements corresponds to a known preoccupation of the new Dean. Sports, camaraderie, honour, money-these were the Empedoclean elements of St

\footnotetext{
102 For example, the flyleaf of Cope's hagiography states "This is the portrait of a genius ...".

103 Colebrook, op. cit., note 98 above, p. 195.

104 Sir Almroth E Wright, Prolegomena to the logic which searches for truth, London, William Heinemann, 1941.

105 Idem, The unexpurgated case against women's suffrage, London, Constable, 1913.
}

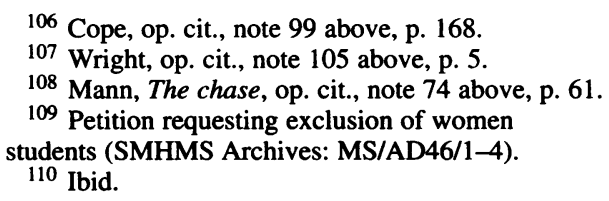

106 Cope, op. cit., note 99 above, p. 168.

107 Wright, op. cit., note 105 above, p. 5.

108 Mann, The chase, op. cit., note 74 above, p. 61.

109 Petition requesting exclusion of women students (SMHMS Archives: MS/AD46/1-4).

110 Ibid. 


\section{James Stuart Garner}

Mary's. The petition is a clever piece of targeted psychology, designed with Charles McMoran Wilson in mind, and, although it may seem bizarre to argue school policy on the basis of sports results, it must be remembered that rugby was a matter of semireligious importance to the contemporary male medical student, particularly in the context of Wilson's totalitarian vision.

The rugby claim which forms the core of the petition requires exploration. Were the rugby results really so dire? Between 1910 and 1914, St Mary's (minus women) won 35 per cent of their matches and lost 65 per cent. From 1919 to 1923 (with women), they won 60 per cent and lost 40 per cent. ${ }^{111}$ Thus it seems that, if anything, the presence of women students improved the rugby performance. Indeed, in 1923, the school won the prestigious Hospital's Cup for only the second time in its history. Clearly the appeals to St Mary's past glories were the product of selective memories. In fact, pre-war rugby at St Mary's was mediocre. A writer in the 1911 Gazette moaned: "Little that is worthy of the recording angel, and nothing that is of good import for the future can be written of the Rugby Club". 112

It would not be fair, however, to ascribe the petition purely to the cynicism of the students. It is unlikely that the writers bothered with a balanced historical analysis, relying instead on anecdote and legend. One of the signatories was a student named John Simpson, who has recalled the event in a recorded interview:

Mainly it was because they [the women students] interfered with the Rugger. We were just getting on the up, just beginning to improve. They thought that if they got rid of the women, they would get more Rugger players [applying to the school]. ${ }^{113}$

By the time the petition reached the Medical School Committee, it had mustered some considerable support among the staff. Although the latter had no obvious reason to oppose the women, few of them were brave enough to resist the exhortations of Almroth Wright, who was actively soliciting support for the petition. In his biography of Alexander Fleming, André Maurois narrated one isolated example of resistance:

One group of male students demanded removal [of the women students]. Some of the doctors thought this would be unfair and put their names to a counter-petition. One of them, a man named Fry, had been taken on at the lab. on Fleming's recommendation, and he felt responsible for him. 'You are making a great mistake, Fry. The Old Man will never forgive you. He hates women students.' 114

It seems clear from this account, and others, that the petition was at least several weeks in the making. It certainly did not arrive on the Dean's desk totally unheralded. In fact, almost a month previously, Wilson had instructed the Hospital Secretary, Colonel Walter Parkes, to investigate the prospect of eliminating female students. His report calculated that the loss of women students would cost the school $£ 8,400$ in fees over the first three

\footnotetext{
111 These statistics are collected from the sporting pages of contemporary issues of the St. Mary's Hospital Gazette, and must be considered only as accurate as the Gazette itself. Although therefore somewhat dubious, they probably provide a good overall sense of rugby performance.
}

112 St. Mary's Hosp. Gaz., 1911, 17: 41.

113 Recorded telephone conversation with the author, dated 23 March 1994.

114 André Maurois, The life of Sir Alexander Fleming: discoverer of penicillin, transl. Gerard Hopkins, London, Jonathan Cape, 1959, p. 105. 
years. ${ }^{115}$ His conclusion was that the school "could, in my opinion, just meet this financially", but he went on to warn that the financial reserves would be severely depleted, and Wilson might find his long-term plans for rebuilding irreparably damaged.

It was financially disadvantageous to the school to cease to admit women students, but the community of St Mary's was in crisis. The Medical School Committee convened on 1 April to consider this dilemma. The meeting was well attended, and the unusually detailed minutes reveal an extremely heated debate. ${ }^{116}$ No solutions were forthcoming, however, and the matter was passed on to the hospital, whose verdict, returned a week later, was that the medical school should cease the admission of women students. ${ }^{117}$ By this stage, the women's supporters had nothing left to offer, and the glee of Almroth Wright is quite evident from the minutes. ${ }^{118}$ It was almost a formality when, on 20 May 1924, the Hospital Board of Management resolved that, with effect from 1925, no further women students should be accepted for admission to St Mary's. ${ }^{119}$ The great experiment was over.

\section{The Fate of the Women}

The 255 women who entered St Mary's between 1916 and 1925 form, in aggregate, a representative cohort of London's early women medical students. A 1936 article in the Lancet reported the results of a postal survey conducted among these women by the St Mary's Hospital Medical Women's Association in May $1934 .{ }^{120}$ The data provides further insight into the lifestyles and careers of those students.

In terms of their time at medical school, 210 of the women came from the LSMW, having completed their pre-clinical training (and, in a few cases, part of their clinical training) at the establishment. Although St Mary's began accepting its own pre-clinical students from September 1920, only thirty-one entered in this way. The small remainder came from other medical schools, principally Oxbridge. Four of the 255 women died before qualification, and twenty-one withdrew during the course, many for financial reasons, leaving a total of 230 qualified students, of whom about 40 per cent carried an MB, BS, the remainder possessing conjoints (see Table 3). Eighty-one of the 230 graduates went on to complete higher professional qualifications or postgraduate degrees of some kind, including MDs, MRCPs and FRCSs.

The opponents of women's medical education often claimed that women rarely made use of their medical training, preferring to opt for a life of conjugal responsibility and child-rearing. Of the 230 St Mary's graduates, 173 were in employment in 1934, just over three-quarters of the cohort. About a third were married, although it is likely that others became so after the completion of the survey (see Table 4). It is true that marriage correlates inversely with employment, but the majority of married women continued to practise medicine, even those who had children. For the sake of comparison, a modern

\footnotetext{
115 Confidential Report, by Colonel Walter Parkes, regarding the consequences of ceasing to admit women students, dated 19/3/1924 (SMHMS Archives: MS/AD46/5).

116 Committee Minutes, entry dated, 1/4/1924, 5: 428 (SMHMS Archives: MS/AD1/5).

117 Sub-Committee Minutes, entry dated 7/4/1924, 3: 73 (SMHMS Archives: MS/AD5/3).
} 


\section{James Stuart Garner}

Table 3

Origins and Qualifications of St Mary's Women Students, 1916-1925

\section{Origins}

London School of Medicine for Women

Other Medical Schools (including Oxbridge)

Native St Mary's Students

Total Number of Women Students, 1916-1925

\section{Qualifications}

Deceased

Withdrawn During Course

Total Qualified Students

$\begin{array}{lrr}\text { LDS } & 1 & 0.4 \% \\ \text { LMSSA } & 2 & 0.9 \% \\ \text { LRCP, MRCS } & 135 & 58.7 \% \\ \text { MB, BS } & 15 & 6.5 \% \\ \text { LRCP, MRCS \& MB, BS } & 77 & 33.5 \%\end{array}$

study indicates that 87 per cent of male doctors and 76 per cent of female doctors get married. ${ }^{121}$ It would be fair to conclude that the medical education received at St Mary's was not wasted on this generation of students.

By 1934, these women were widely dispersed in the medical profession. A large proportion entered general practice, some chose to work in public health, and one became the medical officer to a commercial firm. Two redirected their careers and became dentists. Thirty-two women became hospital specialists, although the traditional male

\section{Table 4}

St Mary's Women Graduates in Employment in 1934

\begin{tabular}{|c|c|c|c|c|c|c|c|}
\hline & Working & $\begin{array}{l}\text { Light } \\
\text { Work }\end{array}$ & $\begin{array}{c}\text { Not } \\
\text { Working }\end{array}$ & Unknown & Dead & \multicolumn{2}{|c|}{ Total } \\
\hline Single & 111 & 1 & 7 & 1 & 7 & 127 & $55.2 \%$ \\
\hline $\begin{array}{l}\text { Married, } \\
\text { no children }\end{array}$ & 19 & 3 & 8 & 1 & - & 31 & $13.5 \%$ \\
\hline $\begin{array}{l}\text { Married, } \\
\text { with children }\end{array}$ & 26 & 10 & 19 & 2 & - & 57 & $24.8 \%$ \\
\hline Unknown & 3 & - & 3 & 6 & 3 & 15 & $6.5 \%$ \\
\hline Total & $\begin{array}{l}159 \\
69.2 \%\end{array}$ & $\begin{array}{l}14 \\
6.1 \%\end{array}$ & $\begin{array}{l}37 \\
16.1 \%\end{array}$ & $\begin{array}{l}10 \\
4.3 \%\end{array}$ & $\begin{array}{l}10 \\
4.3 \%\end{array}$ & $\begin{array}{l}230 \\
100 \%\end{array}$ & \\
\hline
\end{tabular}

121 Isobel Allen, Doctors and their careers, London, Policy Studies Institute, 1988. 
preserves of general medicine and surgery remained elusive (see Table 5). Not until 1993 did Britain witness its first female professor of surgery: Averil Mansfield at St Mary's Hospital. ${ }^{122}$ Remarkable women like Professor Mansfield might be rarer today without the achievements of these 255 predecessors, and others like them, who opened the doors on female medical education.

Table 5

Distribution of St Mary's Women Graduates through the Medical Profession in 1934

\begin{tabular}{|c|c|c|c|c|}
\hline General Practice & & & 87 & $37.8 \%$ \\
\hline in Provinces & 57 & $65.5 \%$ & & \\
\hline in London & 25 & $28.7 \%$ & & \\
\hline Abroad & 5 & $5.8 \%$ & & \\
\hline Specialist (consultant, academic or research) & & & 32 & $13.9 \%$ \\
\hline Physician & 1 & $3.1 \%$ & & \\
\hline Surgeon & 2 & $6.3 \%$ & & \\
\hline Anaesthetist & 5 & $15.5 \%$ & & \\
\hline Gynaecologist & 1 & $3.1 \%$ & & \\
\hline Physiotherapist & 2 & $6.3 \%$ & & \\
\hline Ophthalmologist & 4 & $12.5 \%$ & & \\
\hline Psychotherapist & 4 & $12.5 \%$ & & \\
\hline Radiologist & 1 & $3.1 \%$ & & \\
\hline Physiologist & 2 & $6.3 \%$ & & \\
\hline Pathologist & 4 & $12.5 \%$ & & \\
\hline Research Worker & 4 & $12.5 \%$ & & \\
\hline Medical Journalist & 2 & $6.3 \%$ & & \\
\hline Full-time Resident Hospital Posts & & & 11 & $4.8 \%$ \\
\hline Full-time Public Service and Public Health Posts & & & 12 & $5.2 \%$ \\
\hline Other Full-time Posts & & & 14 & $6.1 \%$ \\
\hline Dentists & & & 2 & $0.9 \%$ \\
\hline Light Work or Part-time Work & & & 14 & $6.1 \%$ \\
\hline Not Working at Present & & & 37 & $16.1 \%$ \\
\hline Unknown & & & 11 & $4.8 \%$ \\
\hline Deceased & & & 10 & $4.3 \%$ \\
\hline
\end{tabular}

\section{Conclusion}

On balance, the great experiment was not a success. It was a revolution of only the most impermanent character: the kind that articulates itself in terms of expediency and convenience rather than principle or ideology. Women were admitted to St Mary's not because it was the right thing to do, but merely because it happened to be useful at the time. These feeble foundations were simply not strong enough to weather the subsequent storms of convention, distrust and injured pride, nor to withstand the vast and ponderous

122 The Times, 15 October 1993. 


\section{James Stuart Garner}

legacy of the nineteenth century. That is why the experiment ended in 1925, and that is why it took another great war to secure the women's return.

But the great experiment hardly seems a failure either. After all, it is a truism of science that an unsuccessful experiment can teach as many lessons as a successful one, and the consequences of this transitory historical episode were rarely less than far-reaching. For St Mary's, the 255 women who entered the school made possible its survival; the school would undoubtedly have closed but for their presence. And for those women who came to St Mary's between 1916 and 1925, the unique circumstances of the period gave them the opportunity to prove their worth against considerable adversity, and to begin the process of staking their claim for equal rights to the practice of medicine-a process which continues to the present day. 